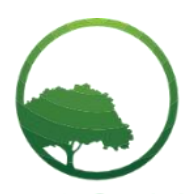

Research in Business \& Social Science

\title{
Strategy, practice and quality of sustainability reports on stock price crash risk

\author{
Dwi Ekasari Harmadji $\bigotimes_{(a)}$, Bambang Subroto@(b), Erwin Saraswati $\left.{ }_{(c)}\right)$,Yeney W. Prihatiningtias $\left(_{(d)}\right.$ \\ (a,b,c,d)Accounting Department, Faculty of Economics and Business, University of Brawijaya, Jl. MT. Haryono, Malang, East Java, Indonesia
}

\begin{tabular}{l} 
A R T I C L E I N F O \\
\hline Article history: \\
Received 01April 20 \\
Received in revised form 23 April 20 \\
Accepted 30 April 20 \\
\hline Keywords: \\
Stock Price Crash Risk (SPCR), \\
Sustainability Reports Strategy, \\
Practice, Sustainability Reports \\
Quality (SRQ) \\
JEL Classification: \\
M41
\end{tabular}

\begin{abstract}
A B S T R A C T
This study examines the relationship between stock price crash risk (SPCR) or the risk of a stock price collapse with strategy, practice, and quality of sustainability reports. This research uses archival data and verification methods. Data analysis using descriptive statistics, regression, classic assumption, and path analysis. This phenomenon arose due to the large number of SPCRs which resulted in losses for investors in the capital market. Samples were taken based on judgment sampling and found 304 reporting studied during the period from 2010-2017 (8 years). The outcomes of this study are the strategy and practice of standalone sustainability reports have a positive effect on the quality of sustainability reports. The quality of sustainability reports (SRQ) mediates the strategy and practice of standalone sustainability reports against SPCR.
\end{abstract}

(C) 2020 by the authors. Licensee SSBFNET, Istanbul, Turkey. This article is an open access article distributed under the terms and conditions of the Creative Commons Attribution (CC BY) license (http://creativecommons.org/licenses/by/4.0/).

\section{Introduction}

Sustainability Reports (SR) that are immediately published to the public by the company will have an impact on increasing share prices. Cho et al., (2012) argues that managers as agents cover non-accounting information in the form of bad news from investors, as well as principals to maintain the careers and compensation of the managers concerned (Bigham and Houston, 2011). Fernandez (2013) states that improving the SR strategy cannot minimize stock price crash risk (SPCR). Kim et al. (2014) states that all sustainability report strategies that demonstrate environmental and social concern are contained in SR. This is real evidence of the behavior of responsible directors. Garcia et al (2013) suggested that investors increasingly trusted to use the SRQ's information as a basis for the decision to buy the company's shares. In contrast, Aman (2013) suggested that the sustainability report strategy had no significant effect on SPCR. This is the basis for conducting research that proves that SRQ can be used as a mediating variable to SPCR. SRQ disclosures has the ability to minimize SPCR (Nazari et al.. 2017).

Research on the effect of SR strategies and practices on SPCR mediated by SRQ, to the best of researchers, has not been done. Another reason is the results of previous studies from Reimsbach et al.. (2017) which is inconsistent with the results of the research of Aman (2013), so researchers need to add the quality of SRQ as an intervening variable to the risk of SPCR. Al-Shaer and Zaman (2016) proves that the SR strategy is not related to the proportion of women as members of the board of directors on SRQ. The results of this study differ from Amran et al.. (2014) which states that one SR strategy relating to proportion of women as directors compared to the total number of directors influences SRQ. Based on the results of previous studies that are still inconsistent and there was a research gap, the researcher is motivated to conduct research on strategies, reporting practices, the quality of sustainability reports on the risk of a stock price collapse. Investors as stakeholders, begin to pay attention to social and environmental issues, so that the use of other non-accounting information is began to emphasize as a basis for decision making (Joseph 2012).

* Corresponding author. ORCID ID: 0000-0003-2845-6379

(C) 2020 by the authors. Hosting by SSBFNET. Peer review under responsibility of Center for Strategic Studies in Business and Finance. https://doi.org/10.20525/ijrbs.v9i3.681 
Based on some of the phenomena and observations mentioned above, the formulation of the research problem is as follows: 1) Do the strategies and practices of the sustainability report affect the stock price crash risk (SPCR)? 2) Does the strategy and practice of the sustainability report affect the quality of the sustainability report? 3) Does the strategy and practice of the sustainability report affect the risk of a stock price collapse mediated by the quality of the sustainability report?

The aims and objectives of this study: i) confirmation stakeholder theory, signaling theory, agency theory and legitimacy theory, ii) providing confirmation of investor perceptions regarding the sustainability report strategy submitted by the Board of Directors, as well as the implementation of reporting practices and the quality of SRQ disclosure in improving information reliability, iii) expected to encourage companies to evaluate risk management and improve SRQ so as to minimize the occurrence of SPCR, iv) providing empirical evidence regarding SR strategies and practices in improving the reliability, transparency and quality of disclosure information in SR,v) evaluating mandatory rules relating to SR, 6) useful for the Financial Services Authority (OJK) regarding SR that are mandatory, so that they can be used as evaluations and basis for improvement regarding the quality of sustainability reporting disclosures as a form of CSR.

The reminder of this study is organized as follows. The next section provides a review of extant literature. The third section introduces methodology and data. Finally, conclusions and implications of the study are presented in the final section.

\section{Literature review}

\section{Theoretical background}

SPCR can be used as an important basis for investors to make investment decisions and manage their stock portfolio. The signaling theory reveals that good quality companies consciously give signals to the market, so that the market is able to distinguish good quality companies from bad ones. Information signals will be good if responded to by the market with good responses and not easily emulated by companies with poor quality (Megginson et al., 2012). Research by Michelon et al.. (2015) proved that three (3) types of SR disclosure practices are: (a) stand-alone reporting, (b) assurance reporting, (c) GRI Guidelines Reporting is associated with the quality of SR disclosure under a symbolic approach. This study also proves the effect of SR practices on disclosure quality, namely Michelon et al.. (2015) prove the effect of SR practices lacking high quality information (Guidry et al., 2012). Financial information, for example earnings, book value, and cash flow is highly irrelevant in SPCR (Reimsbach et al. 2017). Non-accounting information's company contained in the sustainability report (SR) has the ability to reduce stock price crash ris (SPCR) by controlling specific determinants of the risk of a collapse in stock prices (Hamm, 2014). Strategy and mediating role of Sustainability Reports Quality (SRQ) can be considered as a reference in decision making because they contain an information signal from management to stakeholders (Cumming, 2015).

If a business director retains and accumulates bad news for a long time by failing to report internal issues to the company (such as postponed ventures, falling company profits, CEO turnover, etc.), then the stock price of the company will be overvalued. When the collected poor news finally reaches a critical main, all of the poor news will snap be apart on the stock market at once. As a result of all the bad news that was released simultaneously causing a fall in stock prices (Kim et al., 2011). The conduct of the director is constantly with agency theory, which is when the manager as an agent is not transparent in disclosing information by withholding news that should be conveyed to the principal. Managers' concerns about their careers or incentives cause various kinds of deviant behavior of managers which will likely hazard the organizations (Kim et al., 2014). Kim et al., (2014) argues that managerial deviant actions can be stopped, such as covering bad news companies uphold high ethical standards. Henri (2010) states that agency theory offers 2 things: (i) unique insights into information systems, uncertainty, incentives, and risks (ii) valid empirical perspectives, especially when combined with complementary positivist theories. The main recommendation in a company is to incorporate the perspective of the agency in the study of the many problems that have in the company's structure.

The legitimacy theory states that companies must be able to adjust to the value system that has been implemented by the community (Ioannou \& Serafeim, 2015). Corporate business can be realized through social disclosure. This is done with the aim of legitimizing the activities and presence of companies in the public perspective. Amran et al.. (2014) SR practices have high quality information on the practice of SR activities. This is evidenced by the benefits of disclosure of information disclosure and the availability of facilities for decision making, so companies can strengthen their legitimacy. Stakeholder theory focuses primarily on the relationship between companies and stakeholders (Reimsbach et al., 2017). Socio-political theories including stakeholder theory and legitimacy theory have been widely used to explain the practice of sustainability reporting. Stakeholder theory deals with how organizations manage stakeholders. The implementation SRQ becomes very important and gets the attention of all stakeholders (Chauvey et al. 2014, especially investors and risk managers who learn a lot from accounting cases and scandals as a result of the poor quality of disclosure sustainability report. Amran et al., (2014) prove that SRQ disclosure becomes important in the framework of the company's strategy to maintain its stock price from SPCR. In contrast Reimsbach et al.. (2017) states that SRQ is not important in influencing SPCR. Based on the theory of legitimacy (Reimsbach et al., 2017) and signaling theory (Li et al., 2016), the basis for examining SRQ is used as an intervening variable on Stock Price Crash Risk (SPCR). 


\section{Empirical studies and hypothesis development}

Zhang et al., (2015) also explains that the sustainability reporting strategy does not directly influence SPCR. Habib and Mostafa (2017) Arguing that the accumulation of bad news triggers SPCR. This study suggests that managers do not want to give good signals by holding back shareholder bad news due to the short-term job compensation issue and that managers tend to give up when bad long-term news accumulates and crosses a threshold. Inconsistencies occur when Siew (2015) suggest the opposite, that the SR Strategy is a management impression to give a good signal that can be captured by investors, thus significantly affecting SPCR. This research is In line with the signaling theory. Based on previous work and verification of the theory of signaling, the first hypothesis is:

\section{H1: Sustainability reporting strategy negatively affects SPCR}

Stand-alone SR practices are used only to manage good relations with stakeholders (Zhang et al., 2015) or merely opportunistic actions that benefit the company. The issuance of a separate report is expected to provide additional information for investors and stakeholders and improve the quality of sustainability reports as an increase in corporate accountability in meeting stakeholder expectations (legitimacy). On the other hand, the stand-alone SR was issued only as a symbolic act. Voluntary stand-alone SR have opportunities and tendencies to be misused, where the company gives a positive impression that the company seems to be committed to social and environment. This will increase the value of the company's shares, thereby minimizing SPCR. Based on the conceptual framework created, the researcher arranges the following hypotheses:

\section{H2: Stand-alone sustainability report practices negatively affect stock price crash risk}

The ability of assurance practices to increase transparency of sustainability reports that can minimize SPCR (Siew, 2015). There is a tendency for companies to use assurance models that are in accordance with the wishes of the company, this is because there is no standard form of CSR reporting. Research conducted by Cho et al.. (2012) found that assurance does not have a relationship with higher market value for companies that issue CSR reporting, but that the company gets the impression of being more committed to social and environment. Based on this research, it can be understood that the benefits of assurance are only to get a positive impression from stakeholders, so as to increase share prices and minimize SPCR. From this perspective, assurance can be said to be limited to the company's symbolic actions. Based on the conceptual framework created, the researcher arranges the hypothesis as follows:

\section{H3: Assurance sustainability report practices negatively affect stock price crash risk (SPCR)}

Legitimacy theory places organizational survival dependent on many factors, including internal and external relations (Arena et al., 2018). The strategic view of the organization for needs that comes from the perspective of stakeholders is managing all sustainable resources that support legitimacy (Chauvey et al., 2014). The principle of legitimacy notes that businesses must be able to adjust to the community's value system. This perspective is supported by several studies including: Ioannou and Serafeim (2015); Li et al.. (2016) who have found that the contents of sustainability reports are positively charged with little bad news being reported and managers praising themselves. The company uses its sustainability report to give the impression of environmental responsibility, so that the society must recognize the company's presence. This definition tries to shift firmly the company's perspective towards stakeholder orientation. The GRI guidelines sustainability report practice provides quality information to stakeholders. This GRI Guide provides a broad dimension in CSR reporting that has been recognized internationally, so as to increase the company's stock price and minimize the risk of stock crashes (SPCR). The use of GRI guidelines can not be separated from the misuse of the company in its GRI guidelines sustainability practice report. There is a tendency for companies to use guidelines in a biased manner because sustainability reports are voluntary and there are minimal regulations governing them. Siew (2015) states that companies misuse GRI guidelines by trying to meet al.1 GRI indicators, with the aim of improving the assessment of sustainability report practices, so as to minimize the risk of stock crashes (SPCR). The company symbolically uses the GRI guidelines by meeting all indicators, so as to achieve high scores and give a positive impression about the company's commitment to CSR and minimize SPCR. Based on the conceptual framework created, the researcher arranges the hypothesis as follows:

\section{H4: Sustainability report practices guide gri negatively affects stock price crash risk (SPCR)}

The increase in the completeness of the amount of credibility in the information reported, as well as the arising of concerns from stakeholders regarding the overall accountability of SR practice reporting was mentioned in Herbohn et al. (2014) research. Sustainability reporting (SR) practices appear to improve the quality of sustainability reports, in response to stakeholder demands (Michelon \& Parbonetti 2012). The positive influence between SR reporting practices on the quality of sustainability reports tries to integrate the company's relationship with its stakeholders namely: the community, investors, and shareholders (Scholtens and Kang, 2013). Based on theoretical studies and previous research results, the second hypothesis is:

\section{H5: Sustainability report quality (SRQ) mediates strategy for stock price crash risk (SPCR)}

The theory of legitimacy is the basis for companies to get the legitimacy of the existence of the company in a public perspective, the company's reputation increases, and its impact on the value of its shares that are positive in the capital market, so as to minimize stock price crash risk. The Quality of Sustainability Reports can respond to pressures on environmental issues that result in the company's legitimacy being threatened. Sustainability reports can reduce bad news about the company, thereby minimizing stock 
price crash risk. This is also proven by research by Reimsbach et al.. (2017) which states that SRQ (Quality of Sustainability Reports) that can be trusted can provide legitimacy, so that SRQ is used as a basis for decision to buy shares. This has a positive effect on the company's stock price, so that it can minimize stock price crash risk. The Quality of Sustainability Reports (SRQ) can be used as a variable mediating SR strategies and reporting practices on stock price crash risk. Based on theoretical studies and previous research results, the eleventh hypothesis is:

H6: Quality of sustainability reports mediates the effect of stand-alone sustainability report practices on stock price crash risk.

Research by Arena et al.. (2018) proves that companies can disclose information that can strengthen their legitimacy, for example by mentioning environmental awards and awarding sustainability reports that have been achieved, or safety programs that have been implemented by the company if they want to get legitimacy from stakeholders who also environmentalists or employees. The same steps are taken if the company wants to gain legitimacy from shareholders. This is done with the practice of sustainability reports that reveal the superiority of company shares, prospects, profits, and can minimize SPCR. The practice of disclosing sustainability reports is also able to explain the clarification of the company's rebuttal to negative news that might appear in the media. The ultimate goal of obtaining legitimacy is none other than to support the company's main goal in an effort to get maximum profit. Furthermore, this legitimacy will enhance the company's reputation, which in turn will affect the company's value and minimize SPCR. Based on theoretical studies and the results of previous research, the twelfth hypothesis is:

H7: Quality of sustainability report (SRQ) mediates the practice of assurance sustainability report on stock price crash risk.

Research Kim et al.. (2014) also found that companies with high levels of social responsibility had low levels of bad news collection. The relationship of the GRI guidelines sustainability report practice as a corporate social responsibility with the risk of a company's stock crash was further investigated by Kim et al.. (2016) who found that there is a mitigating effect between GRI's sustainability reporting practices on the risk of the company's crash. Furthermore, Kim et al.. (2016) only found a positive relationship between disclosure of corporate social responsibility to the risk of a company's stock crash only when the company had weak corporate governance and a low level of institutional ownership.

Based on a theoretical study and empirical research on the relationship between the role of the GRI guidelines sustainability practice report on the risk of a company's stock price crash before, it can be concluded that there are a number of different opinions and inconsistent research results. Based on these thoughts, the researcher wants to see the relationship between GRI's sustainability reporting practices and company stock price crash risk in Indonesia. Based on the rationale, theoretical study, and the results of previous research, the following hypotheses can be proposed:

H8: Quality of sustainability report (SRQ) mediates GRI Sustainability report practices against stock price crash risk.

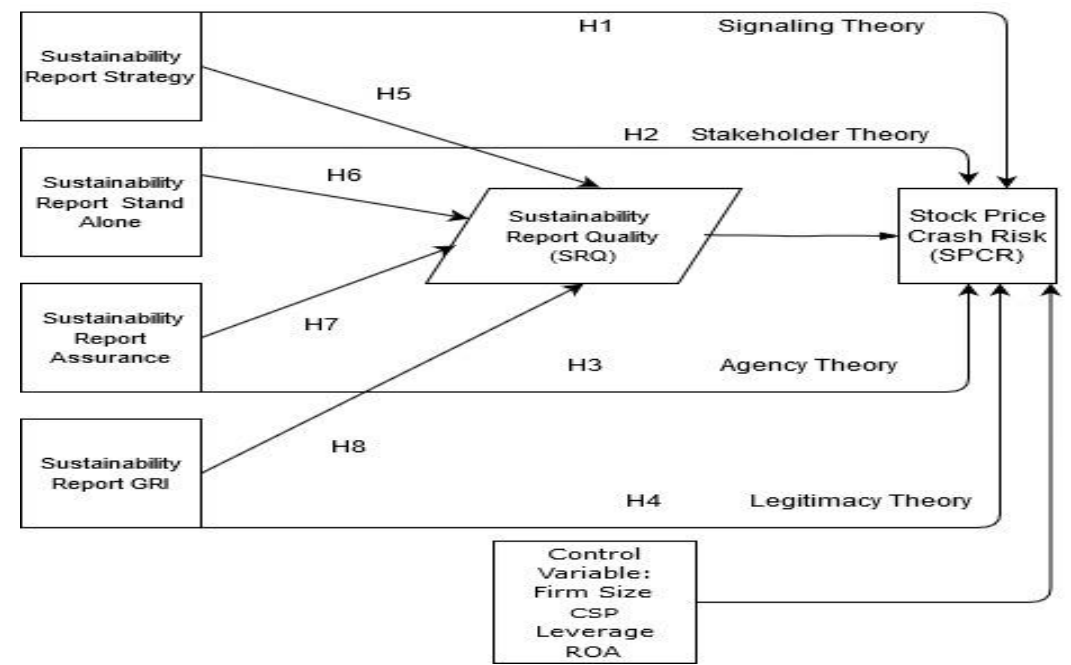

Fig.1: Research model

\section{Research and methodology}

\section{Sample selection}

Sampling chosen in this research is judgment sampling. There are several determinations of the researchers' criteria for using a judgment which include:

1. Manufacturing companies listed on the Indonesia Stock Exchange, and present an annual report between 2010 and 2017.

2. Manufacturing companies whose shares have a high level of liquidity, so that it reflects the real conditions that occur in the stock exchange. This election is due to the fact that some shares are very actively traded, while others only have relatively few transaction 
frequencies and tend to be passive. Liquid stocks are needed to avoid research bias because some stocks have a small trading volume. Stock trading volume is a major component in calculating the distribution of stock returns which is used to measure the risk of stock price crashes.

3. Manufacturing companies that present their financial statements in rupiah. This selection is done because foreign currencies are volatile and to avoid bias when processing data.

4. Manufacturing companies on the Indonesia Stock Exchange which publish Sustainability Reports and Annual Reports with complete data available from 2010 to 2017.

\section{Stock price crash risk (SPCR)}

This analysis, consistent with Habib and Mostafa (2017), uses the dependent variable in the form of SPCR, using two firm-specific SPCR steps. All phases are calculated as residuals from the market model based on company-specific weekly performance. The first indicator of crash risk is the negative conditional slope during the fiscal year (NCSKEW) of the company's unique weekly returns. NCSKEW is determined by taking from the third time the negative of the company-specific weekly return for each year and normalizing it with the standard deviation from company-specific weekly returns to third power. In general, NCSKEW is estimated as the reason for using this metric for each company $\mathrm{j}$ in year $\mathrm{t}$, which is to find out the weekly stock returns that have the potential to experience a sharp decline (negative returns). To measure the negative coefficient of skewness, the calculation below is done.

$$
\text { NCSKEW j,t }=\frac{-\left(n(n-1) 3 / 2 \sum \mathrm{W}_{3 \mathrm{j}, t}\right)}{(\mathrm{n}-1)(\mathrm{n}-2)\left(\sum \mathrm{W}_{2 \mathrm{j}, \mathrm{t}}\right)_{3 / 2}}
$$

NCSKEW = conditional skewness negatively on company return $\mathrm{j}$ for 1 fiscal year $\mathrm{t}$.

$\mathrm{n}=$ Number of weekly returns for 1 year

$\mathrm{W}=$ Company's weekly return in year $\mathrm{t}$

Furthermore DUVOL is used to calculate volatility down-to-up for potential crashes. Weekly returns are divided into two classes for each company: up-week returns more than the annual average and less than the annual average returns. DUVOL doesn't need a second moment, require a third moment (skewedness), so extreme weekly returns do not impact it. The lower the price of DUVOL, the greater the risk of failure (Kim et al., 2014).

$$
\operatorname{DUVOL} \mathrm{j}, \mathrm{t}=-\log \left(\frac{\left(\mathrm{n}_{\mathrm{u}}-1\right) \sum \text { Down } \mathrm{W}_{2 \mathrm{j}, \mathrm{t}}}{\left(\mathrm{n}_{\mathrm{d}}-2\right) \sum \mathrm{Up} \mathrm{W}_{2 \mathrm{j}, \mathrm{t}}}\right)
$$

DUVOL = Volatility down-to-up for potential crashes

$$
\begin{aligned}
& n_{u}=\text { Number of weeks up in years } \\
& N d=\text { Number of weeks down in years } \\
& \sum \text { Down } \mathrm{Wj}, \mathrm{t}=\text { the number of weekly returns down weeks company } \mathrm{j} \text { in year } \mathrm{t} \\
& \sum \mathrm{Up} \mathrm{Wj}, \mathrm{t}=\text { the number of weekly returns up weeks company } \mathrm{j} \text { in year } \mathrm{t}
\end{aligned}
$$

\section{Sustainability reports strategy}

This study uses an independent variable in the form of a Sustainability Reports (SR) Strategy and SR Practices. Four elements in line with Amran et al.. (2014) research were used to determine samples belonging to the SR strategy, That means this: four proxies include: the insight and assignment of the company (VISION), CSR committee (ORG_STR), Collaboration with NGOs (PR_NGO) and gender diversity of directors (GEN_PRO).

Table 1: Measurement of sustainability report strategy

\begin{tabular}{lll}
\hline Elements & Code & Measurement \\
\hline $\begin{array}{l}\text { Vision and Mission of the } \\
\text { Organization / Company }\end{array}$ & & $\begin{array}{l}\text { The company's insight and assignment are measured through three items, namely: } \\
\text { (1) environment, (2) social, (3) proft. Each item is worth one point so the } \\
\text { maximum value is three points which are then divided by three according to the } \\
\text { number of items. }\end{array}$ \\
\hline CSR Committee & ORG_STR & $\begin{array}{l}\text { The CSR committee is measured through } 6 \text { items, namely: (1) objectives, (2) risk } \\
\text { mitigation, (3) determination of CSR activities, (4) reporting, (5) monitoring }\end{array}$ \\
\hline
\end{tabular}


integrated CSR management, (6) training. Each item is worth one point so the maximum value is six points which are then divided by six according to the number of items.

\begin{tabular}{lll}
\hline NGO Collaboration & PR_NGO & $\begin{array}{l}\text { NGO collaboration is measured through } 3 \text { items, namely: (1) the mention of } \\
\text { NGOs, (2) NGO collaboration, (3) the results of NGO and CSR collaboration } \\
\text { activities. Each item is worth one point so the maximum value is three points } \\
\text { which are then divided by three according to the number of items .. }\end{array}$ \\
\hline Gender diversity of directors & GEN_PRO & $\begin{array}{l}\text { Gender Diversity of Directors is measured by a mixed percentage of gender } \\
\text { diversity in the total size of the directors. }\end{array}$ \\
\hline
\end{tabular}

Source: Amran et al., 2014

\section{Sustainability reports practice}

Table 2: Measurement of sustainability report practices

\begin{tabular}{|c|c|}
\hline $\begin{array}{ll}\text { Elements of } \\
\text { Practice SR }\end{array}$ & Measurement \\
\hline Stand-alone & $\begin{array}{l}\text { Stand-alone is measured using a dummy variable equal to } 1 \text { if the company provides a self-sustaining } \\
\text { sustainability report (CSR) and } 0 \text { if the sustainability report (CSR) information is reported in a particular } \\
\text { CSR section of the annual report. The use of this measurement is also based on the logic of measurement } \\
\text { because the type of stand-alone sustainability reporting practice could theoretically affect stock price crash } \\
\text { risk (SPCR). This is in accordance with the research of Michelon et al.. (2015). }\end{array}$ \\
\hline Assurance & $\begin{array}{l}\text { Assurance is measured using the same dummy variable as } 1 \text { if there is a guarantee statement (assurance) } \\
\text { from the Public Accountant Office or an organization that has competence in the field of sustainability } \\
\text { reports (Sustainability Report) and } 0 \text { if there is no guarantee statement (assurance ). The use of this } \\
\text { measurement is also based on the logic of measurement because the type of assurance sustainability practice } \\
\text { practices can theoretically affect stock price crash risk (SPCR). This is in accordance with the research of } \\
\text { Michelon et al.. (2015). }\end{array}$ \\
\hline $\begin{array}{l}\text { GRI (Global } \\
\text { Reporting } \\
\text { Initiative) }\end{array}$ & $\begin{array}{l}\text { The practice of the GRI (Global Reporting Initiative) sustainability report which is measured using a dummy } \\
\text { variable that is equal to } 1 \text { if there is a declaration of compliance with the GRI guidelines and } 0 \text { if there is no } \\
\text { declaration of self-compliance with the GRI guidelines. The use of this measurement is also based on the } \\
\text { logic of measurement because the type of GRI sustainability report practice can theoretically affect stock } \\
\text { price crash risk (SPCR). This is in accordance with the research of Michelon et al.. (2015). }\end{array}$ \\
\hline
\end{tabular}

Source: Michelon et al., 2015

Sustainability reports quality $(S R Q)$

The reason this calculation was used on the basis of logic, measurement because reporting practices can theoretically affect SPCR. The intervening factor in this analysis is SRQ, which is the standard of reporting sustainability that is potentially important for managers and other stakeholders. Report disclosure is an analysis of content used to form a measurement of SRQ using data from published sustainability reports. For the determination of SRQ only sustainability information is disclosed and published in the public domain (www.corporateregister.com). List of GRI reports taken from the internet during the period 2010-2017.

SRQ measurements using Michelon et al.. (2015) to evaluate performance of sustainability reporting (SR) disclosure. They state that there are 3 (three) performance dimensions of sustainability documents focused on: I the quality of the reported data (what and how much is revealed), (ii) Type of information used to clarify issues with CSR (how information is disclosed), and (iii) the management orientation (company approach to CSR). Where the system created is capable of capturing quantitative and qualitative data on voluntary sustainability reporting. The three dimensions are then formulated into 4 (four) indices that can be used as a measurement of SRQ, namely: (i) relative quantity, (ii) density (information density), (iii) accuracy (accuracy of information), and (iv) managerial orientation (management approach). Sustainability report items used to measure the contents of SR disclosure are based on G4 guidelines (GRI, 2013) presented in table 3 and the semantic properties compiled by Michelon, et al., (2015) are presented in table 4. 
Table 3: Classification of Sustainability Reports Information

\begin{tabular}{|c|c|}
\hline Content & \\
\hline Environmental Items & Resources \\
\hline & Power \\
\hline & Water \\
\hline & Biodiversity \\
\hline & Emissions \\
\hline & Waste and effluent \\
\hline & Products and Services \\
\hline & Conformity \\
\hline & Transport \\
\hline & Overall \\
\hline & Supplier Environmental Assessment \\
\hline & Environmental Grievance Mechanisms \\
\hline Social items & \\
\hline labor practice and decent work & Employment \\
\hline & Labor/Management Relations \\
\hline & Occupational Health and Safety \\
\hline & Training and Education \\
\hline & Diversity and Equal Opportunity \\
\hline & Equal Remuneration for Women and Men \\
\hline & Supplier Assessment for Labor Practices \\
\hline & Labor Practices Grievance Mechanisms \\
\hline Human rights & Investment \\
\hline & Non-discrimination \\
\hline & Freedom of Association and Collective Bargaining \\
\hline & Child Labor \\
\hline & Forced of Compulsory Labor \\
\hline & Security Practices \\
\hline & Indigenous Rights \\
\hline & Assesment \\
\hline & Supplier Human Rights Assessment \\
\hline & Human Rights Grievance Mechanisms \\
\hline Society & Local Communities \\
\hline & Anti-corruption \\
\hline & Public Policy \\
\hline & Anti-competitive Behavior \\
\hline & Compliance \\
\hline & Supplier Impact Assessment on Society \\
\hline & Mechanisms of resentment for impact on society \\
\hline Product responsibility & Customer Health and Safety \\
\hline & Product and Service Labeling \\
\hline & Marketing Communications \\
\hline & Customer Privacy \\
\hline & Compliance \\
\hline
\end{tabular}

Source: Michelon et al., 2015 
Table 4: Semantic properties classification SR

\begin{tabular}{ll}
\hline Accuracy & Qualitative \\
& Quantitative \\
Monetary & \\
Managerial orientation & History and aspirations \\
& Initiatives, policies and programs \\
& Objectives and goals \\
& Performance and Outcomes \\
\hline
\end{tabular}

\section{Source: Michelon et al., 2015}

Relative Quantity measures how many items are disclosed by the company compared to the average items revealed by other companies in the same industry. Density measures how many sentences containing relevant information compared to the total sentences disclosed in the SR. Accuracy measures the way companies disclose their sustainability report information. Managerial Orientation (management approach) measures how the company's approach in disclosing its sustainability report information, whether using the Boilerplate Approach or Committed Approach. Boilerplate Approach is a company approach that tends to express expectations and hypotheses in providing expectations in the future, and provides rules, initiatives and strategies in expressing the results. Committed Approach is a company approach that tends to express targets and goals in the future, and provides information about the results and outputs of previous actions. The four dimensions are then combined so that it becomes an index of SRQ/SR disclosure. The mediating variable in this study is SRQ using Michelon's framework; Siew (2015), to assess the sustainability report's value. There are four indices that can be used as a measurement of the quality of disclosure, namely quantity (relative quantity), information density (density), accuracy of information (accuracy), and management approach (managerial orientation). Relative quantity tests how many products a company communicates compared with the average number of items exchanged in the same sector by other firms. You can see the relative quantity in the equation below:

RQTit $=$ Discit $\widehat{\text { Discit }}$

RQTit $=$ Company's relative quantity ratio in the year $t$

Discit $=$ Company i observed rate of disclosure in the year $t$

$\widehat{\text { Discit }}=$ Estimated rate of reporting for company i per year $t$.

Density index tests the number of phrases containing relevant information for GRI G4 compared to the total phrases in the text. Density, the following equation can be seen:

$$
\begin{aligned}
& \text { DENit }= \underset{k_{i t}}{1} \sum_{j=1}^{k_{i t}} \operatorname{CSR} R_{i j t} \\
& \text { DENit }=\text { Company density index } i \text { in year } t
\end{aligned}
$$

$k i t=$ Amount of sentences examined for the business in the report $i$ in year $t$

CSRijt= 1 Where the sentence $\mathrm{j}$ of the report examined for company I includes CSR data in year $\mathrm{t}$, otherwise 0 .

The reliability index tests how businesses in their CSR statements disclose information.

Accuracy, the following equation can be seen:

$$
\text { ACCit }=\underset{n i t}{1} \sum_{j=1}^{n_{i t}}\left(\mathrm{w} * C S R_{i j t}\right)
$$

ACCit $=$ Company accuracy rating $i$ in year $t$

nit $=$ The number of sentences in the report reviewed for the company $i$ that contain CSR data in year $t$

CSRijt $=1$ if the sentence $j$ in the document analyzed for company $i$ in year $t$ contains CSR information, otherwise 0

$w \quad=1$ if the sentence $j$ in the document analyzed for company $i$ in year $t$ is qualitative, $w=2$ if the sentence $j$ in the document analyzed for company $i$ inyear $t$ is quantitative, $\mathrm{w}=3$ if the sentence $j$ in the document analyzed for company $i$ in year $t$ is monetary.

The index of management orientation tests how the organization discloses its SR data. Whether a boilerplate approach or a committed approach can be used by businesses to communicate their SR data. Businesses tend to express general expectations about the future 
in the boilerplate approach and provide guidelines, plans and strategies to communicate results. The company provides shareholders with strategic goals and objectives in a dedicated manner, taking into account the outcomes and performance of the actions taken to meet expectations of stakeholders. Management focus can be seen in the equation below:

$$
\text { MANit }=\underset{n_{i t}}{1} \sum_{j=1}^{n_{i t}}(\text { OBJit } * \text { RESijt })
$$

MANit $=$ Company management orientation measure $i$ in year $t$

nit $=$ The number of sentences in the report examined for company $i$ in year $t$ containing CSR details

OBJit $=1$ Unless, in the report examined for company $i$ in year $t$, sentence $j$ includes CSR data on goals and priorities, otherwise 0

RESijt $=1$ If the sentence $j$ of the report evaluated for company $i$ in year $t$ includes the findings and outcomes of the CSR and 0 otherwise.

The four indexes are then synthesized with the following formula:

Qualityit

$4($ RQTsit + DENsit + ACCsit + MANsit $)$

Definition:

Qualityit $=$ Disclosure reliability obtained from the standardized four index value

RQTsit $=$ Company's relative quantity ratio in the year $t$

DENsit $=$ Company density index $i$ in year $t$

$A C C s i t=$ Company accuracy rating $i$ in year $t$

MANsit $=$ Company management orientation measure $i$ in year $t$

\section{Control Variables}

In this study there are four control variables that are used following the research of Kim et al.. 2016:

Firm Size

Chen et al.. (2018) revealed that firm size is one of the predictors of stock price crash, it was found that negative skewness appeared in large companies. Kim et al.. (2014) then use firm size as a control variable, with the following formula:

Size $=$ Ln Total Assets

CSP (Corporate Social Performance)

Corporate Social Performance is the company's social performance which is an average score of social and environmental pillars. The relationship between CSR disclosure and CSR performance has been proven by previous studies, namely: Cho et al., (2012) and Michelon et al.. (2015). Researchers still use CSP as a control variable even though the results of the study are still diverse. This is done to get more accurate results. Based on this, CSP is an index of CSR performance assessment using CSP guidelines. The CSR performance evaluation formula can be seen in the following formula:

$\mathrm{CSP}_{\mathrm{it}}=\Sigma \mathrm{X}$ it

$\mathrm{n}$

Information:

$\mathrm{CSP}_{\mathrm{it}}=\mathrm{CSR}$ performance of company $\mathrm{i}$ in year $\mathrm{t}$

$\mathrm{X}$ it $=$ Total items disclosed by company $\mathrm{i}$ in year $\mathrm{t}$

$\mathrm{n}=$ Number of disclosure items based on CSP guidelines

\section{Financial Leverage (LEV)}

Financial leverage shows the financing of a company through debt that reflects the value of the company (Kim et al., 2016). According to Chen et al.. (2018), the occurrence of negative asymmetry in market returns reflects a basic economic mechanism. This mechanism, according to Chen et al., (2018) is called the leverage effect, when a decrease in stock prices will increase operating and financial leverage, and consequently will increase the volatility of the return. For this reason, financial leverage is used by Chen $e t$ al.. (2018) and Kim et al.. (2016) as a crash controller. The LEV formula: 


\section{LEV $=$ Total Debt}

Total Assets

Profitability or ROA

Profitability or ROA (Return on Assets) is defined as the ratio between net income after tax and overall total assets (Kim, 2016). Previous research found that profitability has a positive influence on corporate social responsibility and corporate stock returns (Brigham and Houston, 2011). The formula of ROA is as follows:

\section{ROA $=$ Net Profit After Tax \\ Total Assets}

\section{Data analysis methods}

Data analysis in this study as follows: descriptive statistical analysis and classical hypothesis check helps to assess the viability in this research of using a regression model. The classical assumption test of inference performed with a normality test, a heteroscedasticity test, a multicollinearity test, and a test of autocorrelation to test data validity. In this research, the hypothesis test is to use path analysis that is a type of multiple regression application, by using a path diagram as a guide to the testing of complex hypotheses. The sobel test will measure the magnitude of the indirect effect.

\section{Results and Discussions}

Table 5: Results of determination of research samples

\begin{tabular}{llllllllll}
\hline Criteria & Period & & & & & & & Total \\
\hline & 2010 & 2011 & 2012 & 2013 & 2014 & 2015 & 2016 & 2017 \\
\hline $\begin{array}{l}\text { Manufacturing companies listing on the } \\
\text { IDX }\end{array}$ & 105 & 108 & 113 & 135 & 142 & 143 & 149 & 160 \\
\hline $\begin{array}{l}\text { Manufacturing companies whose shares are } \\
\text { not actively traded }\end{array}$ & 2 & 16 & 18 & 23 & 25 & 26 & 29 & 24 \\
$\begin{array}{l}\text { Manufacturing companies whose financial } \\
\text { statements do not use IDR }\end{array}$ & 0 & 0 & 0 & 0 & 0 & 0 & 0 & 0 \\
\hline $\begin{array}{l}\text { Manufacturing companies that have not } \\
\text { published a full sustainability report }\end{array}$ & 96 & 83 & 84 & 85 & 77 & 59 & 55 & 49 \\
\hline Number of Observations & 7 & 9 & 11 & 27 & 40 & 58 & 65 & 87 & $\mathbf{3 0 4}$ \\
\hline
\end{tabular}

Source: Results of data processing, 2019

Table 6: Descriptive analysis

\begin{tabular}{llllll}
\hline & N & Minimum & Maximum & Mean & Standard Deviation \\
\hline STRATEGY & 304 & 0,12 & 0,85 & 0,4071 & 0,17742 \\
\hline PRACTICE STAND-ALONE & 304 & 0,00 & 1,00 & 0,6250 & 0,48492 \\
\hline PRACTICE ASSURANCE & 304 & 0,00 & 1,00 & 0,1414 & 0,34906 \\
\hline PRACTICE GRI & 304 & 0,00 & 1,00 & 0,6053 & 0,48960 \\
\hline SIZE & 304 & 1,16 & 10,66 & 8,2479 & 2,61338 \\
\hline CSP & 304 & 0,10 & 1,00 & 0,7219 & 0,27609 \\
\hline LEVERAGE & 304 & 0,03 & 0,18 & 0,1323 & 0,04558 \\
\hline ROA & 304 & 0,04 & 0,13 & 0,0984 & 0,02825 \\
\hline SRQ & 304 & 0,02 & 0,15 & 0,0326 & 0,02093 \\
\hline SPCR & 304 & $-0,94$ & 2.70 & 0,2165 & 0,47262 \\
\hline Valid N (listwise) & 304 & & & & \\
\hline Soure: Rests
\end{tabular}

Source: Results of data processing, 2019

All of these elements have values that are close to zero, meaning that they have a tight range of data variations, The information is therefore sufficient for use in this analysis. Standard deviation is a significant difference from the average value of the sample.

The classical assumption test

The value of Kolmogorov-Smirnov is 0,105 and significant at 0,000. Ho was rejected, The assumption is that the residual data is not normally distributed and it is reasonable to use regression models in this analysis. 
Table 7: Heteroscedasticity test results

\begin{tabular}{|c|c|c|}
\hline Regression Model 1 & Sig. & Result \\
\hline Strategy & 0,472 & \multirow{4}{*}{$>0.05$ so there is no heteroscedasticity } \\
\hline Stand-alone & 0,516 & \\
\hline Assurance & 0,613 & \\
\hline GRI & 0,516 & \\
\hline Regression Model 2 & Sig. & Result \\
\hline Strategy & 0,521 & \multirow{9}{*}{$>0.05$ so there is no heteroscedasticity } \\
\hline Stand-alone & 0,624 & \\
\hline Assurance & 0,712 & \\
\hline GRI & 0,491 & \\
\hline Size & 0,236 & \\
\hline$C S P$ & 0,135 & \\
\hline Leverage & 0,733 & \\
\hline$R O A$ & 0,368 & \\
\hline$S R Q$ & 0,525 & \\
\hline \multicolumn{3}{|c|}{ 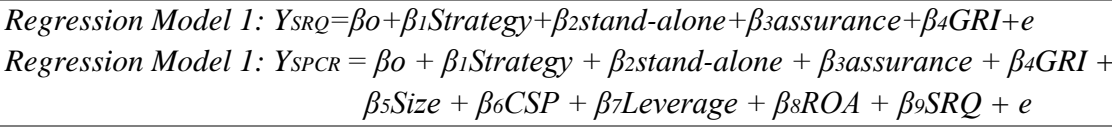 } \\
\hline
\end{tabular}

Source: Results of data processing, 2019

Based on the figures in table 8 , the regression model can be interpreted as homoscedasticity or heteroscedasticity does not occur.

Table 8: Correlation coefficient of the independent variables of strategy, practice and SRQ

\begin{tabular}{llcl}
\hline Model & Covariances & Tolerance & VIF \\
\hline Strategy & $-0,147$ & 0,813 & 1,146 \\
\hline Practice Stand-alone & $-0,164$ & 0,891 & 1,159 \\
\hline Practice Assurance & $-0,139$ & 0,612 & 1,068 \\
\hline Practice GRI & $-0,123$ & 0,524 & 1,047 \\
\hline SRQ & $-0,010$ & 0,925 & 1,054 \\
\hline
\end{tabular}

Source: Results of data processing, 2019)

Practice variables of stand-alone sustainability reports that have a high enough correlation with a correlation level of 0.164 or around $16.4 \%$. This correlation is still below $95 \%$, so it can be said that there is no multicollinearity. The results of the calculation of the tolerance value also shows that there are no independent variables that have a tolerance value of less than 0.10 , which means there is no correlation between the independent variables. The calculation result of VIF (Variance Inflation Factor) also shows the same thing, namely there is no one independent variable that has a VIF value of more than 10 . So, it can be concluded that there is no multicollinearity between independent variables or there is no correlation between independent variables.

The DW value for the SPCR dependent variable of 2,049 will be compared to the table value using a significance value of 5\%, the number of samples (n) is 352 and the number of independent variables $3(k=3)$ in the Durbin Watson table will get the following values: $\mathrm{dL} 1.79726$ and $\mathrm{dU} 1,82410$; then the result $\mathrm{du}<\mathrm{d}<4-\mathrm{du}$ is $1.79726<1.937<2.1759$ so Ho: no positive and negative autocorrelation is accepted, or it can be concluded that there is no autocorrelation. 
Table 9: Hypothesis testing

\begin{tabular}{|c|c|c|c|c|c|c|c|c|}
\hline & \multicolumn{2}{|l|}{ SRQ } & \multicolumn{2}{|l|}{ SPCR } & \multicolumn{3}{|c|}{ Mediation } & \multirow[b]{2}{*}{ conclusion } \\
\hline & B & p-value & $\mathrm{B}$ & p-value & conclusion & $\begin{array}{l}\text { t statistics } \\
\text { (sobel test) }\end{array}$ & $p$-value & \\
\hline Constanta & 0,047 & 0,002 & 0,151 & 0,009 & & & & \\
\hline Strategy & 0,042 & 0,006 & $-0,293$ & 0,001 & $\begin{array}{l}\text { H1 } \\
\text { accepted }\end{array}$ & 8,96 & 0,000 & $\begin{array}{l}\text { H5 } \\
\text { accepted }\end{array}$ \\
\hline Stand-alone & 0,003 & 0,000 & $-0,039$ & 0,002 & $\begin{array}{l}\text { H2 } \\
\text { accepted }\end{array}$ & 4,09 & 0,000 & $\begin{array}{l}\text { H6 } \\
\text { accepted }\end{array}$ \\
\hline Assurance & $-0,008$ & 0,131 & 0,035 & 0,715 & H3 rejected & 0,74 & 0,458 & H7 rejected \\
\hline GRI & $-0,006$ & 0,669 & 0,090 & 0,066 & H4 rejected & 0,80 & 0,421 & H8 rejected \\
\hline Size & & & $-0,014$ & 0,008 & & & & \\
\hline CSP & & & $-0,055$ & 0,005 & & & & \\
\hline Leverage & & & 1,150 & 0,009 & & & & \\
\hline ROA & & & $-0,704$ & 0,003 & & & & \\
\hline SRQ & & & $-3,489$ & 0,004 & & & & \\
\hline
\end{tabular}

*) significance value $\alpha=0,05$ and *) t table $=1,96$ (sobel test)

Source: Results of data processing, 2019.

The first multiple linear regression equation is:

YSRQ $=0.047+0.042$ Strategy +0.003 stand-alone -0.008 assurance $-0.006 \mathrm{GRI}$

The strategy regression coefficient for $\beta=0,042$ which is greater than 0 (positive value) means that the strategy variable is a significant explanation of the sustainability report quality variable (SRQ), so that it is proven that the Sustainability Report Strategy has a positive effect on the Quality of Sustainability Reports (SRQ). The stand-alone practice regression coefficient for $\beta=0.003$ which is greater than 0 means that the stand-alone practice variable is a significant explanation of the sustainability report quality variable (SRQ), so that the stand-alone Sustainability Report Practice has a positive effect on the Sustainability Report Quality (SRQ) has been proven.

The second multiple linear regression equation is:

YSPCR $=0.151-0.293$ Strategy -0.039 stand-alone +0.035 assurance +0.090 GRI

\section{- 0.014Size - 0.055CSP + 1,150Leverage - 0,704ROA - 3,489SRQ}

The strategy regression coefficient for $\beta=-0.293$ which is smaller than 0 means that the strategy variable is a significant explanation of the stock price crash risk (SPCR) variable, so that the H1 hypothesis is accepted, namely the Sustainability Report Strategy has a negative effect on the SPCR has been proven. The stand-alone practice regression coefficient for $\beta=-0.039$ smaller than 0 means that the stand-alone practice variable is a significant explanation of the stock price crash risk (SPCR) variable, so that the H2 hypothesis is accepted, that the Stand-alone Sustainability Report Practice has a negative effect on the proven SPCR. SRQ regression coefficient for $\beta=-3.489$ which is smaller than 0 means that the SRQ variable is a significant explanation of the stock price crash risk (SPCR) variable, so that the quality of the sustainability report has a negative effect on SPCR already proven. There are also four control variables in this research, namely Size, CSP, Leverage and ROA. Of the four variables, for the multiple linear regression equation 2 it turns out that 3 control variables have a significant negative effect and 1 variable has a significant positive effect on the dependent variable stock price crash risk (SPCR). The value of $\beta$ for the control variable size $-0.14<0$ and with the value $\alpha=0.05$ determined, the results of the $t$ test prove sig. $0.008<0.05$ means that the smaller the size (company size), the stock price crash risk (SPCR) will increase. The value of $\beta$ for CSP is $-0.055<0$ and with a value of $\alpha=0.05$ then the results of the t test prove sig. $0.005<0.05$ means that the smaller CSP (Corporate Social Performance) the stock price crash risk (SPCR) will increase. The value of $\beta$ for Leverage $1,150>0$ and with the specified value $\alpha=0.05$, the results of the $t$ test prove sig. $0.009<0.05$ means that the less leverage the stock price crash risk (SPCR) will decrease. The value of $\beta$ for ROA is $-0.704<0$ and with a value of $\alpha=0.05$ then the results of the $t$ test prove sig. $0.003<0.05$ means that the lower the value of ROA (Return on Assets), the stock price crash risk (SPCR) will increase. F test 14.915 with a p-value of 0,000 that is smaller than $0.05(\alpha=0.05)$, then the regression model 1 can be used to predict the Quality of Sustainability Reports (SRQ). F test 1.097 with a p-value of 0,000 that is smaller than 0.05 ( $\alpha=$ 0.05), then the multiple linear regression model 2 can be used to predict stock price crash risk (SPCR). Data processing with SPSS 23 software can be said that the Strategy, Stand-alone, Assurance, GRI, sustainability report quality and control variables Size, CSP, leverage and ROA together influence the stock price crash risk (SPCR).

Path analysis to test hypotheses H5, H6, H7 and H8 have been explained above. Calculations using the sobel test find the mediating effect coefficient value $(\mathrm{t}$ arithmetic $)=8.96$ and 4.09 greater than $\mathrm{t}$ table $=1.96$ with a significance level of 0.05 , it can be concluded 
that there is a mediating effect on the quality of the sustainability report (SRQ) between stand-alone sustainability strategy and practice reports on SPCR. It states that hypotheses H5 and H6 are proven, namely: The quality of sustainability reports mediates the effect of the strategy and practice of stand-alone sustainability reports on stock price crash risk. Hypotheses H7 and H8 were rejected because from the sobel test it was found that the mediating effect coefficient value ( $\mathrm{t}$ arithmetic) $=0.74$ and 0.80 is smaller than $\mathrm{t}$ table $=1.96$ with a significance level of 0.05 then it can be concluded that there is no mediating effect the quality of the sustainability report (SRQ) between the practice of sustainability assurance reports and the practice of GRI's sustainability reports with SPCR. It states that hypotheses $\mathrm{H} 7$ and $\mathrm{H} 8$ are not proven, namely: The quality of sustainability reports does not mediate the effect of the practice of sustainability assurance reports and the practice of GRI sustainability reports on stock price crash risk.

\section{Sustainability reporting strategy negatively affects SPCR}

Hypothesis $1(\mathrm{H} 1)$ test results reveal that a progress in the sustainability reporting strategy would reduce the risk of a stock price crash risk (SPCR) and vice versa if the sustainability reporting strategy decreases, It will raise the SPCR threat. It indicates that the approach of the sustainability study is based on four metrics (Amran, 2014), namely: Vision and Mission (Arena et al., 2018), CSR Committee, Collaboration with NGOs, Directors' Gender Diversity (Siew, 2015) still has a significant influence on SPCR. Confirmation of the signaling theory, the results of this study are evident, namely the behavior of the company's management in providing guidance (signals) to stakeholders regarding the determination of the sustainability report strategy and management's view of the company's prospects in the future. The outcomes of this study are also consistent with the Brigham and Houston (2011) results of previous studies that the ranks of management (directors) as agents stated the strategy Sustainability reports are management's impressions to provide good signals that can be captured by investors, thus significantly affecting SPCR.

Stand-alone sustainability report practices negatively affect stock price crash risk

Hypothesis 2 test results reveal that a progress in the stand-alone SR practices would reduce the risk of a stock price crash risk (SPCR) and vice versa if the stand-alone sustainability report report practices decreases, it will raise the SPCR threat. The results of this study are consistent with previous research that is the reference of this study, namely Michelon et al. (2015) that publishing stand-alone reports adds to the quality of sustainability reports. In line with the research of Fernandez et al. (2013) that the voluntary disclosure of CSR information is the company's goal to meet the needs of stakeholders.

Stakeholder theory is confirmed on the results of this study with evidence that the practice of the stand-alone sustainability report will provide a positive signal to stakeholders about the company's prospects in the future, so that interest arises in buying company shares, and has an impact on minimizing SPCR.

Assurance sustainability report practices has no negatively affect stock price crash risk (SPCR)

The results of the test $\mathrm{H} 3$ were ignored. The results of this study prove that the practice of sustainability assurance reports has no negative effect on stock price crash risk (SPCR). The practice of sustainability assurance reports will not reduce stock price crash risk (SPCR). Panel data analysis of 304 sample companies for the period 2010-2017 shows that the practice of voluntary assurance sustainability reports acts as a legitimacy tool implemented by companies in Indonesia in response to normative, coercive and mimetic pressures. This is in accordance with the research of Arena et al., (2018) which proves that the practice of voluntary assurance sustainability reports increases and is not followed by a decrease in stock price crash risk (SPCR). His research is in manufacturing companies in several countries that have a larger legal system and cultural development, especially in the manufacturing industry who are very concerned about sustainability reports. This is more likely to issue an assurance statement. Research by Michelon et al. (2015) proves that the practice of high sustainability sustainability reports is also related to the higher quality of disclosure of sustainability reports, because it aims only symbolically, not substantially. The Sustainability Assurance Report Practice provides more relevant information about the company. The relevant information can be interpreted CSR information is only ceremonial philanthropic, and does not expose the company's true commitment, because it disguises the important things of the disclosure itself. This resulted in the practice of sustainability assurance reports not having a negative effect on SPCR

Sustainability report practices guide GRI has no negatively affects stock price crash risk (SPCR)

The results of the test $\mathrm{H} 4$ were ignored. In the Indonesia Stock Exchange, it is evident from this research that the practice of sustainability reports in addition to using the GRI standard, some companies use several other standards namely ISO26000 and Proper, so that the GRI standard is not the only standard used by the company. The practice of voluntary GRI sustainability reports is only with the aim of gaining legitimacy from stakeholders, this confirms the theory of legitimacy. The practice of sustainability reports in accordance with the theory of legitimacy will provide reasonable results to carry out the task of accountability to shareholders. They can represent symbolic actions designed for companies that are committed to CSR practices correctly. This research is in line with research by Michelon et al. (2015) that improving the quality of sustainability reports can provide legitimacy for companies.

Sustainability report quality (SRQ) mediates strategy for stock price crash risk (SPCR)

The results of testing hypothesis 5 (H5) are accepted, because found that the quality of sustainability reports as an intervening variable mediated the effect of the sustainability report strategy on SPCR. The theory of legitimacy is confirmed and becomes the basis for 
companies to obtain legitimacy of the existence of the company in a public perspective, so that the company's reputation increases and the impact on share prices that go up in the capital market, this is able to minimize the risk of SPCR.

The results of previous studies also prove that the quality of sustainability reports mediates the effect of the sustainability reporting strategy on SPCR, namely the results of research by Alotaibi, et al., (2018) and the research of Michelon et al. (2015). The results of this study are also consistent with the results of previous studies from Kim, et al. (2016) who predicted SPCR in the future. This research also proves that quality sustainability reports can minimize SPCR. Andreou, et al., (2016) found that investors place orders for an expected higher return for their shares. This shows that this research captures the same and consistent phenomenon, because it shows the quality of sustainability reports that are negatively correlated and significant with SPCR.

\section{$S R Q$ mediates the effect of the sustainability report strategy on SPCR}

The results of testing hypothesis 6 (H6) were not proven because the quality of sustainability reports did not mediate the effect of the strategy and practice of sustainability reports on SPCR. This is in line with Michelon et al. (2015) that three 3 (three) dimensions of the level of sustainability reports are based on: (i) the quality of the revealed data (what and how much is revealed), (ii) Type of data used to classify the CSR problem (how information is released) and (iii) the management orientation (CSR approach). This dimension was compiled based on research conducted by Michelon et al., (2015) and Nazari et al., (2017) by creating a framework that can capture quantitative and qualitative information relating to the disclosure of voluntary sustainability reports. The three dimensions are then formulated into 4 (four) indices that can be used as a measurement of the quality of sustainability reports, namely: (i) relative quantity, (ii) density (information density), (iii) accuracy (accuracy of information), and (iv) managerial orientation (management approach).

The results of this study show the novelty that SRQ is only an intermediate factor which mediates the impact of the strategy for sustainability reporting on SPCR. Legitimacy theory is the basis for companies to obtain the legitimacy of the existence of the company in a public perspective, so that the company's reputation increases and the impact on rising share prices in the capital market, this is able to reduce the risk of SPCR. This study's results are also coincide with the outcome of previous Kim, et al. (2014) studies that predicted SPCR in the future. This research also proves that quality sustainability reports can minimize SPCR. Research Andreou, et al. (2016) found that investors make orders for a higher expected return for their shares.

\section{Conclusions}

The strategy and practice of the stand-alone SR has a positive effect on the quality of the sustainability report. This means that the higher the value of the sustainability strategy and stand-alone practice report which has a positive effect. The higher the quality of the sustainability report and vice versa. The strategy, quality and practice of stand-alone sustainability reports negatively affect Stock Price Crash Risk (SPCR); it means that the higher the value of the stand-alone strategy, quality and practice of sustainability reports, the lower the SPCR value will be and vice versa.

The Quality of sustainability report (SRQ) mediates the strategy and practice of stand-alone sustainability reports on stock price crash risk (SPCR). This is the novelty of this research. The quality of sustainability reports does not mediate the effect of the assurance and GRI sustainability reporting practices on stock price crash risk. The practice of sustainability assurance and GRI reports does not have a positive effect on the quality of sustainability reports. The practice of sustainability assurance and GRI reports does not negatively affect stock price crash risk.

The study results are very relevant for investors and public companies on the Indonesian stock exchange, because it provides confirmation to investors that the strategy can improve the quality of sustainability reports. This can affect investor considerations in making decisions to invest by evaluating their portfolio based on corporate social, economic and environmental responsibility activities. As the quality of the Sustainability Report increases, managers are restricted from manipulating stock prices by stockpiling bad news to increase short-term earnings. This must be considered by Indonesian regulators and investors to improve corporate governance. The results show that the quality of sustainability reports can complement internal governance, which can be promoted by bringing changes to existing financial market regulations. Empirical evidence from this research will improve the reliability, transparency and quality of disclosure information in sustainability reports. This can be used as a policy basis for the Financial Services Authority (OJK) so that sustainability reports can be mandatory.

Limitations of this study are: The results of statistical calculations for the coefficient of determination $\left(\mathrm{R}_{2}\right)$ are small, so there are many other factors that are influential and are outside the existing regression model. The limitations of this study are also limited data until 2017 due to the presence of several companies that have not published a 2018 sustainability report.

Suggestions that can be given to further researchers are to add data until 2018 and expand data on the capital markets of other countries, for example ASEAN countries or ASIA; and need to add variables that have not been examined in this study, such as GCG, Cost of Capital, religion, culture, as well as adding moderation variables and other mediating variables that can be the novelty of further research. Further studies can also be carried out to prove whether the signals captured from the sustainability report quality information are in line with the company's future performance. It is also possible to carry out further research to explore whether the strategy, practice and level of sustainability reports actually contribute more empirically to sustainable development, this is a problem that goes beyond current research. 


\section{References}

Alotaibi, K. \& Hussainey, K. (2018). Quantity Versus Quality: The Value Relevance of CSR Disclosure of Saudi Companies. Corporate Ownership and Control Journal 13(2), 167-79.

Al-Shaer, H., and Zaman, M. (2016). Board gender diversity and sustainability reporting quality. Journal of Contemporary Accounting and Economics, 12(3), 210-222. https://doi.org/10.1016/j.jcae.2016.09.001

Aman, H. (2013). An Analysis of the Impact of Media Coverage on Stock Price Crashes and Jumps: Evidence from Japan. PacificBasic Finance Journal 24(1), 22-38.

Amran, A., Lee, S. P., and Devi, S. S. (2014). The influence of governance structure and strategic corporate social responsibility toward sustainability reporting quality. Business Strategy and the Environment, 23(4), 217-235. https://doi.org/10.1002/bse.1767

Andreou, P. C., Antoniou, C., Horton, J., and Louca, C. (2016). Corporate Governance and Firm-specific Stock Price Crashes. European Financial Management, 22(5), 916-956. https://doi.org/10.1111/eufm.12084

Arena, C., Michelon, G., Trojanowski, G. (2018), Big Egos Can Be Green: A Study of CEO Hubris and Environmental Innovation. British Journal of Management (2018), 15(2), 16-29 https://doi: 10.1111/1467-8551.12250

Brigham, E. F., and Houston, J. F. (2011). Dasar-dasar Manajemen Keuangan. (A. A. Yulianto, Ed.) (11th ed.). Jakarta: Salemba Empat.

Chauvey, J. N., Giordano, S., Cho, C. H., and Patten, D. M. (2014). The Normativity and Legitimacy of CSR Disclosure: Evidence from France. Journal of Business Ethics, 130(4), 789-803. https://doi.org/10.1007/s10551-014-2114-y

Chen, Y., Xie, Y., You, H., dan Zhang, Y. (2018). Does crackdown on corruption reduce stock price crash risk. Journal of Corporate Finance, 51(C), 125-141

Cho, C. H., Michelon, G., and Patten, D. M. (2012). Impression management in SR: An empirical investigation. Accounting and the Public Interest, 12(1), 16-37. https://doi.org/10.2308/apin-10249

Cumming, D., Leung, T. Y., and Rui, O. (2015). Gender diversity and securities fraud. Academy of Management Journal, 58(5). https://doi.org/10.5465/amj.2013.0750

Fernandez, P. (2013). Company Valuation Methods. Iese Business School-Universidad De Navarra, 1-20. https://doi.org/10.1016/0305-0483(73)90101-1

García, M. A., Sierra, L., and Zorio, A. (2013). Financial crisis impact on sustainability reporting. Management Decision, 51(7), 1528-1542. https://doi.org/10.1108/MD-03-2013-0102

Global Reporting Initiative (GRI). (2013) Pedoman Pelaporan Keberlanjutan G4 (Retrieved from: www.globalreporting.org/7-52018).

Guidry, R. P., and Patten, D. M. (2012). Market reactions to the first-time issuance of corporate sustainability reports: Evidence that quality matters. Sustainability Accounting Management Policy Journal, 1(1), 33-50. https://doi.org/10.1108/20408021011059214

Habib, A., dan Mostafa, M.H. (2017). Business Strategy, Overvalued Equities, and Stock Price Crash Risk. Research in International Business and Finance, 39(1), 389-405

Hamm, S. J. W., Li, E. X., and Ng, J. (2014). Management earnings guidance and stock price crash risk, 1-47. https://doi.org/10.2139/ssrn.2055008

Henri, J.-F., and Journeault, M. (2010). Eco-control: The influence of management control systems on environmental and economic performance. Accounting, Organizations and Society, 35(1), 63-80. https://doi.org/10.1016/j.aos.2009.02.001

Herbohn, K., Walker, J., and Loo, H. Y. M. (2014). Corporate Social Responsibility: The Link Between Sustainability Disclosure and Sustainability Performance. Abacus, 50(4). https://doi.org/10.1111/abac.12036

Ioannou, I., and Serafeim, G. (2015). The impact of CSR on investment recommendations: Analysts' perceptions and shifting institutional logics. Strategic Management Journal, 36(7), 1053-1081. https://doi.org/10.1002/smj.2268

Joseph, G. (2012). Ambiguous but tethered: An accounting basis for sustainability reporting. Critical Perspectives on Accounting, 23(2), 93-106. https://doi.org/10.1016/j.cpa.2011.11.011

Kim, J.-B., Li, Y., and Zhang, L. (2011). Corporate tax avoidance and SPCR: Firm analysis. Journal of Financial Economics, 100(3), 639-662. https://doi.org/10.1016/j.jfineco.2010.07.007

Kim, J., and Zhang, L. (2016). Does Accounting Conservatism Reduce SPCR? Firm-level Evidence. Unpublished Working Paper, City University of Hong Kong, 23-47. https://doi.org/10.2139/ssrn.1521345

Kim, Y., Li, H., and Li, S. (2014). CSR and SPCR. Journal of Banking and Finance, 43(1), 1-13. https://doi.org/10.1016/j.jbankfin.2014.02.013

Li, X., Wang, S. S., and Wang, X. (2016). Trust and SPCR: Evidence from China. Journal of Banking and Finance, 8180(March). https://doi.org/10.1016/j.jbankfin.2016.12.003

Megginson, L. C., Pietri., P. H., and Mosley, D. C. (2012). Management (12th ed.). Thomsville, Alabama, USA: Sage Publication Ltd.

Michelon, G., and Parbonetti, A. (2012). The effect of corporate governance on sustainability disclosure. Journal of Management and Governance, 16(3), 477-509. https://doi.org/10.1007/s10997-010-9160-3 
Michelon, G., Pilonato, S., and Ricceri, F. (2015). Corporate Social Responsibility reporting practices and quality of disclosure. Critical Perspectives on Accounting, 33, 59-78. https://doi.org/10.1016/j.cpa.2014.10.003

Nazari, J. A., Herremans, I. M., \& Warsame, H. A. (2017). Sustainability Reporting: External Motivators and Internal Facilitators. Corporate Governance, 12(3), 25-37.

Reimsbach, D., Hahn, R., and Gürtürk, A. (2017). Integrated Reporting and Assurance of Sustainability Information: An Experimental Study on Professional Investors' Information Processing. European Accounting Review, 1-23. https://doi.org/10.1080/09638180.2016.1273787

Scholtens, B., and Kang, F.C. (2013). Corporate social responsibility and earnings management: Evidence from Asian Economics. Corporate Social Responsibility and Environmental Management, 20(2), 95-112.

Siew, R. Y. J. (2015). A review of corporate sustainability reporting tools (SRTs). Journal of Environmental Management, 164, 180195. https://doi.org/10.1016/j.jenvman.2015.09.010

Zhang, M., Xie, L., and Xu, H. (2015). Corporate Philanthropy and Stock Price Crash Risk: Evidence from China. Journal of Business Ethics, 595-617. https://doi.org/10.1007/s10551-015-2647-8 